\title{
Hubungan Dukungan Keluarga dengan Kelengkapan Imunisasi Dasar Balita di Desa Mumbulsari
}

\author{
Yuni Handayani \\ STIKES dr. Soebandi Jember, yunih579@gmail.com
}

\begin{abstract}
ABSTRAK
Imunisasi telah terbukti sebagai salah satu upaya kesehatan masyarakat yang sangat penting. Melalui imunisasi dapat menunjukkan keberhasilan yang besar karena merupakan usaha dalam mencegah penyakit menular dengan biaya yang tidak mahal. imunisasi dipengaruhi oleh beberapa faktor, diantaranya tingkat pengetahuan, usia ibu, jenjang pendidikan, pekerjaan, jumlah anak dan dukungan keluarga. Penelitian ini bertujuan untuk menganalisa Hubungan Dukungan Keluarga dengan Kelengkapan Imunisasi Dasar Balita di Desa Mumbulsari Kecamatan Mumbulsari - Jember. Pada tahun 2015, Jawa Timur menyumbang kasus difteri terbesar (63\%) dan belum memenuhi target SPM (Standart Pelayanan Minimal). Menurut profil kesehatan Kabupaten Jember 2014 dari 49 Puskesmas, terdapat 4 Puskesmas yang belum mencapai target UCI diantaranya adalah puskesmas Kalisat (92\%), Pakusari (86\%), Bangsalsari (86\%) dan Mumbulsari (75\%). Desain penelitian ini menggunakan korelasi dengan pendekatan Cross Sectional. Populasi 90 ibu yang memiliki anak bawah usia dua tahun. Setelah memakai rumus slovin didapatkan 73 responden sebagai sampel dengan menggunakan tekhnik simple random sampling. Hasil penelitian menunjukkan Imunisasi dasar lengkap 53 (73\%) dan Imunisasi dasar tidak lengkap 20 (27\%), dukungan keluarga baik 58 (79,5\%), dukungan keluarga kurang 15 (20,5\%). Uji analisa data menggunakan Spearman Rank dengan p-value 0,000< $\alpha 0,05$ yang berarti ada hubungan dukungan keluarga dengan kelengkapan imunisasi dasar Balita. Disarankan agar selanjutnya masyarakat yang mempunyai anak bawah dua tahun memberikan dukungan yang baik kepada ibu untuk pemberian imunisasi dasar lengkap.
\end{abstract}

Kata kunci: dukungan keluarga, kelengkapan imunisasi dasar

\begin{abstract}
Immunization has proven to be one of the most important public health efforts. Immunization programs shown remarkable success funds are a very cost-effective effort in preventing infectious diseases. Immunization is influenced by several factors, including knowledge level, mother's age, education level, occupation, number of children and family support. This aims to analyze the Relationship of Family Support with the completeness of Basic Immunization Balita in Village Mumbulsari of Sub-districts Mumbulsari - Jember. In 2015, East Java accounted for the largest diphtheria cases (63\%) and has not met the target of SPM (Minimum Service Standards). According to the health profile of jember district 2014 Of 49 health centers, there are 4 other health centers that have not reached the target of UCI are Kalisat health center (92\%), Pakusari (86\%), Bangsalsari (86\%) and Mumbulsari (75\%). This research design use correctional with Cross Sectional approach.Population 90 mothers who have children under the age of two years.After slovin formula obtained 73 respondents as sample by using simple random sampling technique. The result showed Basic Immunization of complete $53(73 \%)$ and Basic Immunization of incomplete 20(27\%), good family support 58(79,5\%), less family support 15 (20,5\%). Data analysis test using Spearman Rank with p-value 0,000< $<0,05$ which means there is a Family Support Relationship with Basic Immunization Equipment Balita. It is recommended that the next community who have a child under two years give family good support to basic immunization for granting mothers complete.
\end{abstract}

Keywords: family support,basic immunization completeness

* Korespondensi Author : Yuni Handayani, SST., MM, STIKES dr. Soebandi, yunih579@ gmail.com,085331044052

\section{PENDAHULUAN}

Imunisasi telah terbukti sebagai salah satu upaya kesehatan masyarakat yang sangat penting. Program imunisasi dapat menentukan tingkat keberhasilan dan merupakan usaha dalam mencegah penyakit menular dengan biaya yang murah. ${ }^{1}$ Seorang bayi atau Balita dikatakan dengan status lengkap apabila telah menyelesaikan 5 imunisasi dasar yaitu BCG, DPT, Hepatitis B, Polio dan Campak dengan jumlah pemberian yang sesuai dosis dan waktunya. Namun belum terpenuhinya cakupan imunisasi di beberapa daerah karena dipengaruhi oleh beberapa faktor, diantaranya faktor predisposisi yang ditunjukkan dari pengetahuan, sikap, kepercayaan, keyakinan serta nilai-nilai. 
Selain itu faktor pendukung yang ditunjukkan dalam lingkungan fisik seperti ketersediaan fasilitas, jarak menuju sarana pelayanan kesehatan, dan faktor pendorong yang yaitu sikap dan perilaku, petugas kesehatan atau petugas lain serta dukungan keluarga dan tokoh masyarakat. $^{2}$

Data WHO menunjukkan Cakupan imunisasi di India mencapai $83 \%$. India telah mengeliminasi polio dan baru-baru ini tetanus pada bayi baru lahir dan ibu hamil. India bekerja keras dalam mencapai target wilayah dalam hal eliminasi campak tahun $2020.85 \%$ bayi di dunia menerima vaksinasi lengkap. Afrika selangkah lebih dekat untuk sertifikasi bebas polio dengan penghapusan Nigeria dari negara endemis polio sejak tahun 2014. Secara keseluruhan cakupan vaksinasi di Afrika mendekati 80\% (77\% pada tahun 2014). Cakupan imunisasi dasar di Indonesia pada tahun 2015 sebesar 86,54\%. Cakupan angka ini belum memenuhi capaian target Renstra pada tahun 2015 yaitu sebesar $91 \%$. Sedangkan menurut provinsi, terdapat sepuluh provinsi (29\%) yang mencapai target Renstra tahun 2015. Kasus difteri di Provinsi Jawa Timur sebesar $74 \%$ hal ini menjadi kontributor terbesar dari seluruh kasus pada tahun 2014. Sedangkan pada tahun 2015 Jawa timur juga masih terdapat kasus difteri terbesar (63\%). Cakupan desa/kelurahan UCI di Jawa Timur tahun 2014 sebesar 87,50 \%. Pencapaian UCI tingkat desa/kelurahan tahun 2010-2014 cenderung meningkat dari $50,81 \%$ menjadi $83,9 \%$ pada tahun 2014. Cakupan UCI pada tahun 2014 ini belum memenuhi target SPM (Standart pelayanan minimal) dan sasaran pembangunan kesehatan Kabupaten Jember. Menurut situasi imunisasi di Kabupaten Jember dalam profil kesehatan Kabupaten Jember 2014 Dari 49 Puskesmas yang dipantau, terdapat 45 Puskesmas yang telah mencapai target UCI (Universal Child Immunitation) tahun 2014 sebesar 95\%. 4 Puskesmas lainnya yang belum mencapai target UCI adalah puskesmas Kalisat (92\%), Pakusari (86\%), Bangsalsari $(86 \%)$ dan Mumbulsari (75\%).

Berdasarkan Hasil Studi pendahuluan didapatkan 8 balita di Desa Mumbulsari yang berusia 12-24 bulan mendapatkan Imunisasi dasar lengkap dan mendapat dukungan Kurang dari keluarga berupa keluarga melarang anaknya untuk diimunisasi takut anaknya sakit, keluarga lupa mengingatkan jadwal ibu datang keposyandu, keluarga tidak ada yang mengantarkan ibu keposyandu. sedangkan 4
(50\%) Balita tidak mendapatkan imunisasi dasar lengkap dan mendapat dukungan yang baik dari keluarga berupa keluarga selalu mengingatkan ibu mengenai jadwal posyandu, keluarga mendukung dari adanya program imunisasi.

Pemberian imunisasi lengkap pada anak dipengaruhi oleh banyak faktor, salah satunya adanya dukungan keluarga. Adanya dukungan dari keluarga akan memberikan motivasi kepada ibu untuk membawa anak mendapatkan imunisasi sesuai dengan jadwal pemberian. Tetapi dengan tidak adanya dukungan keluarga akan mempengaruhi sikap ibu dalam melaksanakan imunisasi kepada anak. 22 Dukungan keluarga akan membantu orang tua dalam melengkapi status imunisasi bayinya.Anggota keluarga dapat memberi dukungandalam bentuk informasi, emosional,penghargaan dan dukungan instrumental. ${ }^{1}$

Imunisasi salah satu pencegahan primer yang sangat efektif untuk menghindari terjangkitnya penyakit infeksi, dengan demikian angka kejadian penyakit infeksi akan menurun, kecacatan serta kematian yang ditimbulkannya pun akan berkurang jika anak sudah mendapatkan imunisasi dasar legkap. ${ }^{3}$ Jika imunisasi dasar lengkap sudah tercapai target dan cakupannya, maka akan mengurangi tingginya angka kematian dan kesakitan pada anak balita dan juga akan mengurangi terjadinya KLB (Kejadian Luar Biasa) pada penyakit campak, diferi, tetanus neonatorum, poliomyelitis dan hepatitis $\mathrm{B}$, demikian juga sebaliknya jika pemberian imunisasi dasar lengkap tidak efektif akan meningkatkan angka kesakitan dan kematian yang justru akan memperburuk kondisi anak balita dan dapat menurunkan kekebalan tubuh pada anak. ${ }^{4}$

\section{METODOLOGI}

Metode Penelitian ini adalah penelitian kuantitatif dengan menggunakan pendekatan cross sectional dengan sorrelational study. Tempat pelaksanaan penelitian ini di Desa Mumbulsari Kecamatan Mumbulsari-Jember. Adapun Populasi ibu yang mempunyai anak dibawah 2 tahun sebanyak 90 Balita dan menggunakan rumus solvin untuk menentukan sample dalam penelitian ini sehingga didapakan hasil sebanyak 73 responden, menggunakan tekhnik pengambilan sampling simple random sampling. Dengan kriteria kriteria Inklusi :

a. Ibu yang memiliki balita usia 12-24 bulan.

b. Bersedia untuk dijadikan responden. 
c. Ibu yang masih mempunyai Buku KIA.

d. Berdomisili di Desa Mumbulsari.

Kriteria Eksklusi : Ibu yang saat penelitian dilakukan, pindah tempat tinggal di luar Desa Mumbulsari. Alat ukur berupa kuesioner dan ceklist dengan menggunakan Untuk menganalisa data pada penelitian ini menggunakan Analisa Bivariate karena terdapat dua variabel yang diduga berhubungan atau berkorelasi. Analisis data pada penelitian ini menggunakan Uji Koefisien Korelasi Spearman's Rank.

\section{HASIL DAN PEMBAHASAN}

a. Karakteristik Responden Berdasarkan Usia di Desa Mumbulsari Kecamatan Mumbulsari - Jember tahun 2020.

Tabel 1. Karakteristik Responden Berdasarkan Usia Ibu Yang Mempunyai Anak Bawah Dua Tahun di Desa Mumbulsari tahun 2020

\begin{tabular}{lcc}
\hline \multicolumn{1}{c}{ Usia } & Jumlah & Persen \\
\hline$<20$ tahun & 4 & 5,5 \\
$20-35$ tahun & 65 & 89 \\
$>35$ tahun & 4 & 5,5 \\
\hline Total & 73 & 100 \\
\hline
\end{tabular}

b. Karakteristik Responden Berdasarkan Pekerjaan di Desa Mumbulsari Kecamatan Mumbulsari-Jember tahun 2020.

Tabel 2. Karakteristik Responden Berdasarkan Pekerjaan Ibu Yang Mempunyai Anak Bawah Usia Dua Tahun di Desa Mumbulsari tahun

\begin{tabular}{lcc} 
& 2020 & \\
\hline \multicolumn{1}{c}{ Pekerjaan } & Jumlah & Persen \\
\hline Tani & 3 & 4,1 \\
Wiraswasta & 2 & 2,7 \\
Tidak Bekerja & 68 & 93,1 \\
\hline Total & 73 & 100 \\
\hline
\end{tabular}

c. Karakteristik Responden Berdasarkan Pendidikan Ibu di Desa Mumbulsari Kecamatan Mumbulsari-Jember tahun 2020

Tabel 3. Karateristik Responden Berdasarkan pendidikan di Desa Mumbulsari Kecamatan Mumbulsari-Jember tahun 2020

\begin{tabular}{lcc}
\hline \multicolumn{1}{c}{ Pekerjaan } & Jumlah & Persen \\
\hline SD & 24 & 32,9 \\
SMP & 30 & 41,1 \\
SMA & 19 & 26 \\
\hline Total & 73 & 100 \\
\hline
\end{tabular}

d. Identifikasi Dukungan Keluarga di Desa Mumbulsari Kecamatan Mumbulsari Jember.

Tabel 4. Distribusi frekuensi Dukungan Keluarga di Desa Mumbulsari Kecamatan Mumbulsari - Jember tahun 2020

\begin{tabular}{lcc}
\hline \multicolumn{1}{c}{$\begin{array}{c}\text { Dukungan } \\
\text { Keluarga }\end{array}$} & Jumlah & Persen \\
\hline Baik & 58 & 79,5 \\
Kurang & 15 & 20,5 \\
\hline Total & 73 & 100 \\
\hline
\end{tabular}

e. Identifikasi Kelengkapan Imunisasi Dasar Anak Bawah Dua Tahun di Desa Mumbulsari Kecamatan Mumbulsari - Jember.

Tabel 5. Distribusi frekuensi Kelengkapan Imunisasi Dasar Anak Bawah Dua Tahun di Desa Mumbulsari Kecamatan Mumbulsari Jember tahun 2020

\begin{tabular}{lcc}
\hline $\begin{array}{c}\text { Kelengkapan } \\
\text { Imunisasi Dasar }\end{array}$ & Jumlah & Persen \\
\hline Lengkap & 53 & 73 \\
Tidak Lengkap & 20 & 27 \\
\hline Total & 73 & 100 \\
\hline
\end{tabular}

f. Hubungan Dukungan Keluarga dengan kelengkapan Imunisasi Dasar di Desa Mumbulsari Kecamatan Mumbulsari Jember.

Tabel 6. Tabulasi Silang antara Dukungan Keluarga dengan Kelengkapan Imunisasi Dasar Anak Bawah Dua Tahun di Desa Mumbulsari Kecamatan Mumbulsari - Jember tahun 2020

\begin{tabular}{lcccc}
\hline Dukungan & \multicolumn{3}{c}{ Kelengkapan Imunisasi Dasar } \\
\cline { 2 - 5 } Keluarga & \multicolumn{4}{c}{} \\
\cline { 2 - 5 } & Lengkap & Tdk Lengkap & Total & P-Value \\
\hline Baik & $50(68,5 \%)$ & $10(13,6 \%)$ & $60(82,1 \%)$ & 0,000 \\
Kurang & $0(0 \%)$ & $13(17,8 \%)$ & $13(17,8 \%)$ & \\
\hline Total & $50(72,6 \%)$ & $23(27,4 \%)$ & $73(100 \%)$ & \\
\hline
\end{tabular}

\section{Identifikasi Dukungan Keluarga di Desa Mumbulsari Kecamatan Mumbulsari- Jember tahun 2020 \\ Berdasarkan hasil penelitian yang} dilakukan di Desa Mumbulsari Dukungan 
Keluarga baik sebesar 58 (79,5\%) dan dukungan keluarga kurang sebesar 15 (20,5\%).

Dukungan keluarga adalah sikap, tindakan dan penerimaan keluarga terhadap anggotanya. Pandangan anggota keluarga terhadap seseorang hanya bersifat mendukung dan selalu siap dalam memberikan pertolongan dan bantuan jika diperlukan. ${ }^{5}$

Berdasarkan kajian teori, dukungan keluarga dapat diartikan sebagai bentuk informasi verbal dan non verbal, saran, bantuan yang nyata atau tingkah laku yang diberikan orang-orang dekat dan memberikan keuntungan emosional serta berpengaruh pada tingkah laku penerimanya. Sehingga seseorang tersebut merasa memperoleh dukungan merasa lega karena diperhatikan, mendapat saran atau kesan yang menyenangkan pada dirinya. ${ }^{2}$ Pada hakekatnya keluarga diharapkan mampu untuk mewujudkan timbal balik rasa cinta dan kasih sayang antara anggota keluarga dan antar generasi yang merupakan dasar keluarga yang harmonis. $^{5}$

Berdasarkan alasan tersering ibu tidak mengimunisasi anaknya adalah ibu lupa jika ada jadwal posyandu. Jika dukungan keluarga baik, hal ini bisa diminimalisir. Anggota keluarga lain yang mengasuh Balita bisa bertanggungjawab untuk membawa ke fasilitas kesehatan untuk mendapatkan imunisasi sesuai dengan jadwal.

\section{Identifikasi Kelengkapan Imunisasi Dasar Anak Bawah Usia Dua Tahun di Desa Mumbulsari Kecamatan Mumbulsari- Jember tahun 2020}

Berdasarkan hasil penelitian yang dilakukan di Desa MMumbulsari sebanyak 53 (73\%) orang tua yang memiliki anak bawah dua tahun dan mendapat imunisasi dasar Lengkap, dan sebanyak 20 (27\%) pada kategori Tidak Lengkap, Tingkat pendidikan SMP $30(41,1 \%)$.

Imunisasi adalah suatu bentuk intervensi kesehatan yang sangat efektif dalam menurunkan angka kematian bayi dan Balita. Dengan imunisasi dapat mencegah berbagai penyakit diantaranya TBC, difteri, pertusis, tetanus, Hepatitis B, poliomielitis, dan campak. Pentingnya pemberian imunisasi dapat dilihat dari banyaknya balita yang meninggal akibat penyakit yang dapat dicegah dengan imunisasi (PD3I). ${ }^{6}$

Hal ini sesuai dengan teori, Dikatakan anak bawah dua tahun mendapatkan imunisasi dasar lengkap jika anak mendapatkan 5 imunisasi dasar yaitu BCG, HB, Polio, DPT dan
Campak. Imunisasi dasar lengkap diberikan pada anak bawah dua tahun dan anak jika mendapat imunisasi dasar yang lengkap anak tidak akan mudah terserang penyakit dan tidak mudah tertular orang yang sakit. Sebaliknya jika anak tidak mendapat imunisasi dasar lengkap anak akan mudah terserang penyakit dan mudah tertular orang yang sakit. ${ }^{4}$

Alasan tersering yang dikemukakan ibu untuk tidak melengkapi imunisasi anaknya adalah ibu lupa jika ada jadwal posyandu atau pada saat jadwal imunisasi anak dalam keadaan sakit. Perilaku yang diteliti dalam penelitian ini adalah, perilaku ibu yang mengimunisasikan anaknya ke pelayanan kesehatan yang berada di Desa Mumbulsari. Peneliti hanya melihat kelengkapan imunisasi dasar anak melalui buku KIA (Kartu Ibu dan Anak) yang dimiliki responden.

Sebagian besar responden dalam penelitian ini melakukan imunisasi anaknya secara lengkap dengan baik. Dikarenakan adanya dukungan keluarga yang baik sehingga adanya kemauan untuk imunisasi lengkap. Kelengkapan imunisasi dalam pembentukannya merupakan suatu perilaku yang mempunyai nilai sangat penting karena dukungan keluarga yang baik tidak akan berarti jika tidak diimbangi dengan pelaksanaan yang baik.

\section{Hubungan dukungan keluarga dengan kelengkapan imunisasi dasar Balita di Desa Mumbulsari Kecamatan Mumbulsari - Jember tahun 2020}

Berdasarkan hasil penelitian yang mendapat dukungan keluarga baik yang diberi imunisasi dasar lengkap 50(68,5\%), dukungan keluarga baik yang diberi imunisasi dasar tidak lengkap 10(13,6\%). dukungan keluarga kurang yang diberi imunisasi dasar lengkap $0(0 \%)$, dan dukungan keluarga kurang yang diberi imunisasi dasar tidak lengkap 13(17,8\%).

Berdasarkan Hasil uji spearman rank diperoleh $p$-value $0,000<0,05$ maka $\mathrm{Ho}$ ditolak dan $\mathrm{Ha}$ diterima sehingga ada hubungan dukungan keluarga dengan kelengkapan imunisasi dasar Balita di Desa Mumbulsari Kecamatan Mumbulsari - Jember tahun 2020.

Dukungan keluarga adalah domain yang sangat penting dalam kelengkapan imunisasi dasar. Berdasarkan dari pengalaman dan penelitian terbukti bahwa dukungan keluarga yang baik akan mempengaruhi tingkat kelengkapan imunisasi dasar pada anak bawah usia dua tahun. ${ }^{7}$ 
Hal ini sesuai dengan teori bahwa dukungan keluarga diartikan sebagai suatu informasi baik berupa verbal dan non verbal, saran, bantuan yang nyata atau tingkah laku yang diberikan orang-orang akrab yang memberikan keuntungan emosional dan berpengaruh pada tingkah laku penerimanya. ${ }^{5}$ Selain itu, kelengkapan imunisasi dapat dipengaruhi oleh tingkat pendidikan anggota keluarga.Tingkat pendidikan yang lebih tinggi akan memudahkan seseorang untuk menyerap informasi dan mengimplementasikannya dalam perilaku dan gaya hidup sehari-hari khususnya dalam masalah kesehatan. Sebagian besar Ibu atau sebanyak $30(41,1 \%)$ ibu berlatarbelakang dengan pendidikan sampai SMP. ${ }^{4}$

Pekerjaan juga dapat mempengaruhi kelengkapan imunisasi dasar. Karena ibu yang mempunyai anak bawah dua tahun yang mendapat imunisasi dasar lengkap hampir seluruhnya atau sebanyak $68(93,1 \%)$ tidak bekerja hanya sebagai ibu rumah tangga. Dan biasanya ibu yang terlalu sibuk dengan pekerjaan akan lupa akan pemberian imunisasi sesuai jadwal. Beberapa faktor yang mempengaruhi kelengkapan imunisasi dasar yaitu usia ibu karena diketahui bahwa usia yang paling aman seorang ibu untuk melahirkan anak adalah 20 sampai 30 tahun. Jenjang pendidikan karena ibu yang memiliki tingkat pendidikan yang tinggi akan memberikan imunisasi lebih lengkap kepada anaknya dibandingkan ibu dengan pendidikan rendah. Pekerjaan karena pekerjaan dapat memberikan kesempatan suatu individu untuk sering kontak dengan individu lainnya, bertukar informasi dan berbagi pengalaman dan dapat saling bertukar informasi tentang program-program kesehatan khususnya imunisasi.

\section{SIMPULAN DAN SARAN}

Adapun kesimpulan dari penelitian ini antara lain sebagai berikut:

a. Sebagian besar ibu yang memiliki anak bawah dua tahun mendapat dukungan baik dalam pemberian imunisasi dasar lengkap.

b. Sebagian besar anak bawah dua tahun mendapat imunisasi dasar lengkap.

c. Ada Hubungan antara Dukungan Keluarga dengan Kelengkapan Imunisasi Dasar Balita di Desa Mumbulsari Kecamatan Mumbulsari - Jember tahun 2020.

Sedangkan saran yang penulis berikan antara lain sebagai berikut: a. Menjadikan masukkan untuk dapat meningkatkan cakupan sasaran imunisasi supaya masyarakat memahami pentingnya kelengkapan imunisasi pada balita supaya terhindar dari penyakit dan dapat meningkatkan mutu pelayanan dalam memberikan imunisasi pada balita.

b. Penelitian ini diharapkan keluarga memberikan dukungan baik terhadap ibu yang memiliki anak bawah dua tahun untuk pemberian imunisasi dasar lengkap .

c. Adanya penelitian berikutnya tentang imunisasi dasar lengkap dengan menggunakan variabel yang berbeda dan lebih mempersiapkan diri guna melakukan penelitian selanjutnya yang lebih sempurna sehingga kegunaannya dapat dirasakan oleh berbagai pihak, serta sebagai Sumber dalam melakukan penelitian yang berhubungan dengan imunisasi dasar lengkap.

\section{UCAPAN TERIMA KASIH}

Terima kasih kepada seluruh pihak yang telah berperan serta dalam kegiatan penelitian ini yaitu responden dan utamanya STIKES dr. Soebandi Jember dan Puskesmas Mumbulsari yang telah memfasilitasi terlaksananya penelitian ini.

\section{REFERENSI}

1. Proverawati Atikah. Imunisasi dan Vaksinasi. Yogyakarta: Nuha Medik ; 2010.

2. Candra Mei E. Urgenitas peran dukungan keluarga terhadap kelengkapan Imunisasi dasar pada balita di RW 1 Kelurahan Bangsal Kecamatan Pesantren Kota Kediri. Skripsi. Sekolah tinggi ilmu kesehatan RS Baptis Kediri; 2014.

3. Ditarahmaika A.,S.keb. faktor-faktor yang berhubungan dengan status imunisasi dasar pada bayi Di kelurahan mergosono kecamatan kedung kandang kota malan. Skripsi. Sekolah tinggi ilmu kesehatan maharani malang Program studi d-III kebidanan; 2015.

4. Janu Pramadita. hubungan tingkat pengetahuan, usia dan pekerjaan ibu dengan status imunisasi dasar bayi; 2012.

5. Evelyn T.E. Hubungan dukungan keluarga dengan perilaku merokok di Smp 14 Kabupaten jember. Skripsi. Program Studi Ilmu Keperawatan STIKES dr. Soebandi Jember; , 2016.

6. Dewi Vivian N. L. Asuhan Neonatus Bayi dan Balita. Jakarta: Salemba Medika; 2010.

7. Suprajitno, S,Kp. Asuhan keperawatan keluarga : Aplikasi dalam praktik. Jakarta. Penerbit buku kedokteran EGC; 2008. 